\title{
P-169 前立腺癌の女性ホルモン療法について
}

相川泌尿器科医院

相川英男

最近前立腺のホルモン療法としては抗男性ホルモン庵法が主流となっている。抗男性ホルモン廉法中 十分な改善が得られない、あるいは再然した患者に対し女性ホルモン骶を投与した所、著名な内視鏡所 見の改善およびマーカーの減少を見た。この事から抗男性ホルモン療法と女性ホルモン㞠法とは作用機

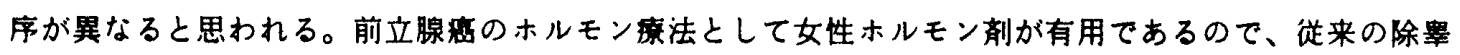
術に代わり抗男性ホルモン都を使用し、その上、女性ホルモン绪も併用する治暴法が良いように思われ ろ。

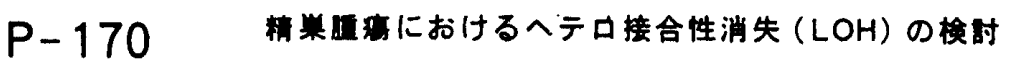

\section{京都大学 泌尿器科}

三品睦輝，小川管，木下秀文，筧 鲁行，寺地敏郎，岡田裕作，吉田 修

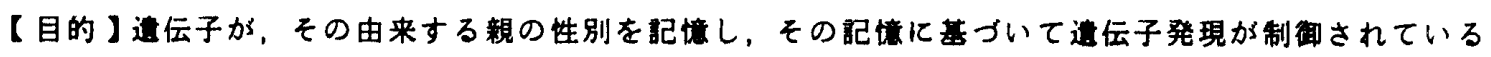

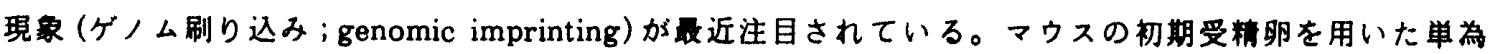

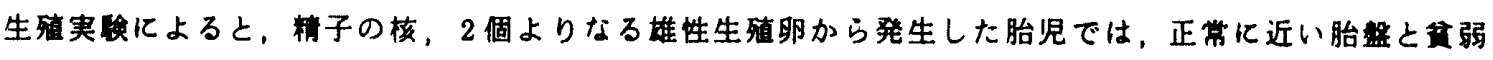

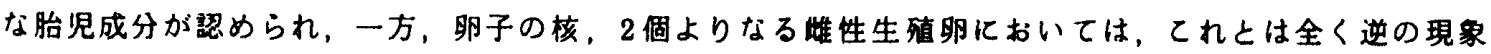

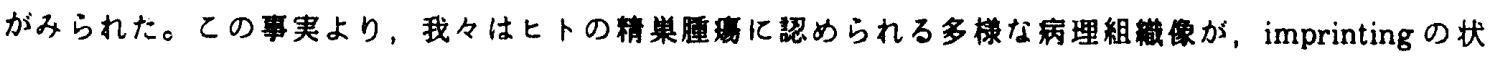
慜の变化によるののである可能性を考えた。そてで，まずヒトにおいても imprintingが证明されている

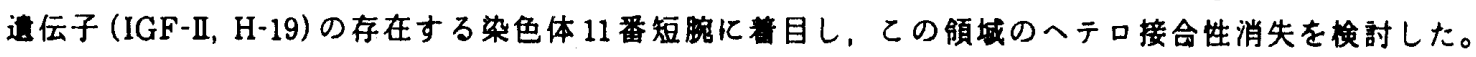

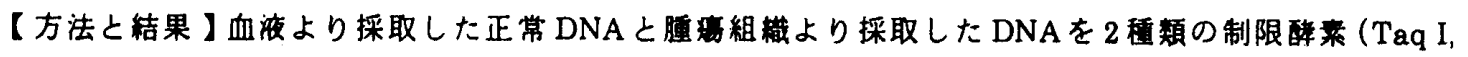
Msp I)で消化し，染色体 $11 \mathrm{p}$ 上にある4種類のプローベ(H-RAS, Calcitonin, Insulin, D11S16)を用いた

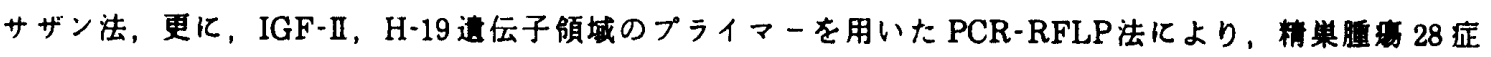
例 [ seminoma 17例, non-seimonoma 11例] のRFLP解析を行った。8症例 (29\%) [ seminoma 5例， non-seimonoma 3 例]において LOHを珰めた。現在欠失 alleleの父母由来を梌封中である。 